\title{
Premenstrual exacerbation of life-threatening asthma: Effect of gonadotropin releasing hormone analogue therapy
}

\author{
ALUN L EDWARDS MB FRCPC, M SARAH ROSE PhD, LOIS E DONOVAN MD FRCPC, \\ GORDON T FORD MD FRCPC \\ Department of Medicine, Calgary General Hospital, and Department of Community Health \\ Services, University of Calgary, Calgary, Alberta
}

\begin{abstract}
AL Edwards, MS Rose, LE Donovan, GT Ford. Premenstrual exacerbation of life-threatening asthma: Effect of gonadotropin releasing hormone analogue therapy. Can Respir J 1996;3(3):203-206.

Variability in the severity of asthma during various phases of the menstrual cycle has been frequently suspected. However, the hormonal changes that might affect mediators of bronchospasm have yet to be elucidated. The case of a 41year-old woman suffering from longstanding asthma with life-threatening exacerbations is reported. The patient was treated with buserelin, a gonadotropin releasing hormone $(\mathrm{GnRH})$ analogue, which created a temporary chemical menopause and thus permitted diagnosis of a premenstrual exacerbation of asthma and offered insight into potential therapy. GnRH analogues may therefore be of value in assessing women with severe asthma suspected to vary with the menstrual cycle. The addition of estrogens and progestins at the same time as treatment with GnRH analogue may be of value in determining the role of these hormones in the pathogenesis of menstrually related exacerbations of asthma.
\end{abstract}

Key Words: Asthma, Gonadotropin releasing hormone analogue, Menstrual cycle
Exacerbation prémenstruelle de l'asthme quasi mortel : effet du traitement avec un analogue de la gonadolibérine

RÉSUMÉ : On a souvent émis l'hypothèse que la gravité de l'asthme variait au cours des différentes phases du cycle menstruel. Cependant, les changements hormonaux qui pourraient affecter les médiateurs du bronchospasme restent à élucider. Le cas d'une femme de 41 ans souffrant d'asthme de longue date et de crises d'asthme quasi mortelles est décrit. La patiente a été traitée avec de la buséréline, analogue de la gonadolibérine $(\mathrm{Gn}-\mathrm{RH})$, qui a créé une ménopause chimique temporaire, en nous permettant ainsi de diagnostiquer une exacerbation de l'asthme en période prémenstruelle, et en nous éclairant sur un traitement éventuel. Les analogues de la Gn-RH pourraient donc s'avérer utiles pour évaluer les femmes souffrant d'asthme grave suspecté de varier avec le cycle menstruel. L'addition simultanée d'oestrogènes et de progestatifs au traitement avec l'analogue de la Gn-RH pourrait être utile pour déterminer le rôle de ces hormones dans la pathogenèse des exacerbations de l'asthme liées au cycle menstruel.

Correspondence and reprints: Dr Alun Edwards, Division of Endocrinology, Bow Valley Centre, Calgary General Hospital, 841 Centre Avenue East, Calgary, Alberta T2E 0A1. Telephone 403-268-9683, fax 403-268-9196, e-mail aedwards@acs.ucalgary.ca 
$\mathrm{I}_{\mathrm{i}}^{\mathrm{n}}$ some women, the severity of asthmatic symptoms may increase during the few days preceding the start of the menstrual cycle. This temporal relationship has been examined in several studies, but the results have failed to confirm the hypothesis that premenstrual hormonal changes adversely influence the severity of asthma (1-8). Attempts have been made to use endocrine manipulation to improve premenstrual asthma, without consistent success $(4,8)$.

We report a patient who suffered life-threatening episodes of asthma. Buserelin, a gonadotropin releasing hormone (GnRH) analogue, was prescribed and succeeded in abolishing the menstrual cycle for six months. During this time the patient experienced a dramatic reduction in symptoms and an increase in peak expiratory flow (PEF). The therapy also allowed the examination of individual hormone replacement on the patient's respiratory function.

We believe that in the exceptional cases of severe asthma in women, GnRH analogue therapy can be used to assess the role of reproductive hormones. This may provide guidance in future therapy and may provide the means to study the endocrine-mediated factors involved in this condition.

\section{CASE PRESENTATION}

A 41-year-old school librarian had suffered from asthma since childhood. She recognized several triggers of exacerbations, including respiratory infections, cold air, peanuts, pollens and animal danders. Her asthma was severe and she had been admitted to hospital on seven occasions over a two-year period (three of these to the intensive care unit) while many other episodes were managed in frequent visits to the emergency room or the respiratory medicine clinic.

She harboured a suspicion that the asthma was always more troublesome in the 10 days preceding the onset of menses. Upon finally revealing this notion to her physician she was asked to use a mini-Wright's peak flowmeter twice a day, record the results and keep a diary of exposure to her known environmental triggers, prednisone therapy, and days of menstrual flow. She kept immaculate records in both tabular (Figure 1) and graphic formats for three consecutive years. Three selected consecutive three-month periods are illustrated in Figure 2.

Although asthma is a notoriously variable condition, examination of her records over a number of months tended to confirm that her belief that PEF dipped premenstrually or that she often required the addition of oral glucocorticoid therapy at this time. We decided to attempt confirmation by rendering the patient anovulatory and amenorrheic. This end was achieved in reversible fashion with the GnRH analogue buserelin acetate, administered as a nasal spray in a dose of $400 \mu \mathrm{g}$ three times a day. The treatment was continued for six months, during which time she was amenorrheic. Her PEF improved dramatically - usually measuring $300 \mathrm{~L} / \mathrm{min}$ (Figure 2). She did not require admission to hospital and suffered few exacerbations and only when clearly exposed to known environmental triggers. She took prednisone orally for only 23 days in six months, having used prednisone in doses exceeding $20 \mathrm{mg} /$ day on 37 days in the 10 weeks preceding

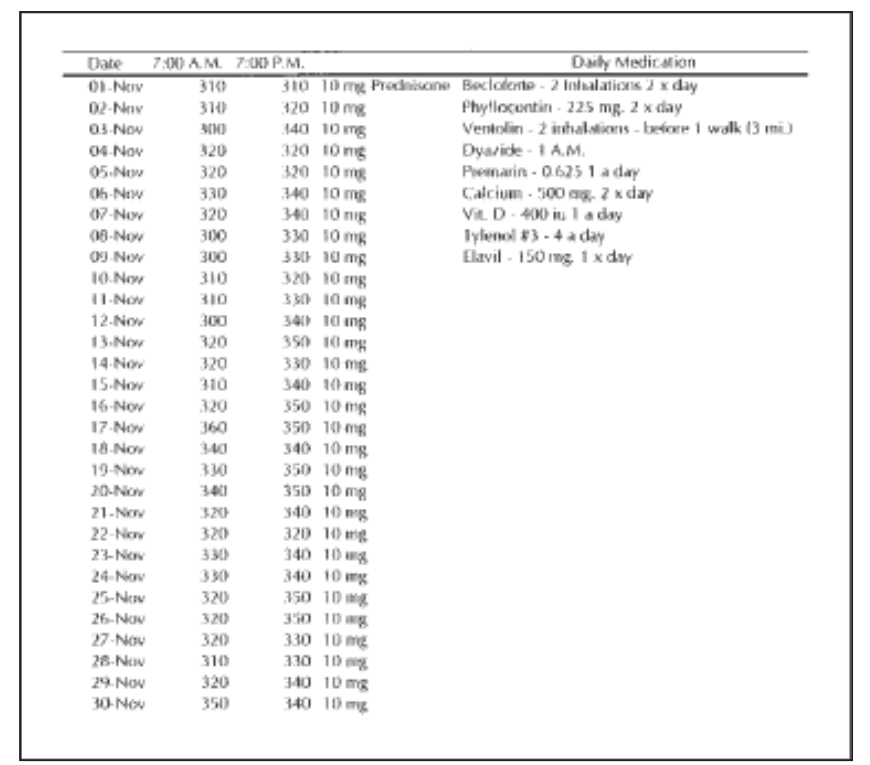

Figure 1) An example of the patient's record keeping for a single month (see Figure 2, bottom for November, following bilateral salpingo-oophorectomy) to illustrate the fastidiousness of her own record keeping

buserelin treatment. At the onset of the seventh month on buserelin she was also prescribed conjugated estrogen 0.625 mg daily; her PEF did not change. Medroxyprogesterone acetate $5 \mathrm{mg}$ daily was added to the regimen after 15 days to complete the commonly employed replacement strategy for amenorrheic women. Within four days of the addition of the progestin her PEF began to decline precipitously and she required prednisone. Buserelin, estrogen and progestin were all discontinued. For the next three months, the patient required not less than $15 \mathrm{mg}$ of prednisone daily and her PEF rarely exceeded $200 \mathrm{~L} / \mathrm{min}$. She felt that her quality of life had improved so much during buserelin therapy that its continuation was discussed. The relative expense of buserelin lead to the conclusion that long term therapy constituted an excessive financial burden.

After extensive discussion the patient was offered the possibility of ovariectomy; she determined this to be worth the potential improvement in her asthma and consented to the procedure. A hysterectomy was also recommended to permit the use of unopposed estrogen therapy, which appeared not to have caused a deterioration in a short term trial and which would be required to maintain a low risk status for osteoporosis and cardiovascular disorders. Since the procedure, the patient's asthma has been much easier to control. She has not required hospitalization for acute asthma and her prednisone requirements have decreased dramatically (Figure 1, Figure 2 bottom). She has had fewer than one to two emergency room visits for asthma per year.

\section{DISCUSSION}

A number of clinical observations suggest that reproductive endocrine status can influence the natural history and severity of a variety of diseases. Asthma is one such disorder, where severity might vary during the menstrual cycle. Anec- 


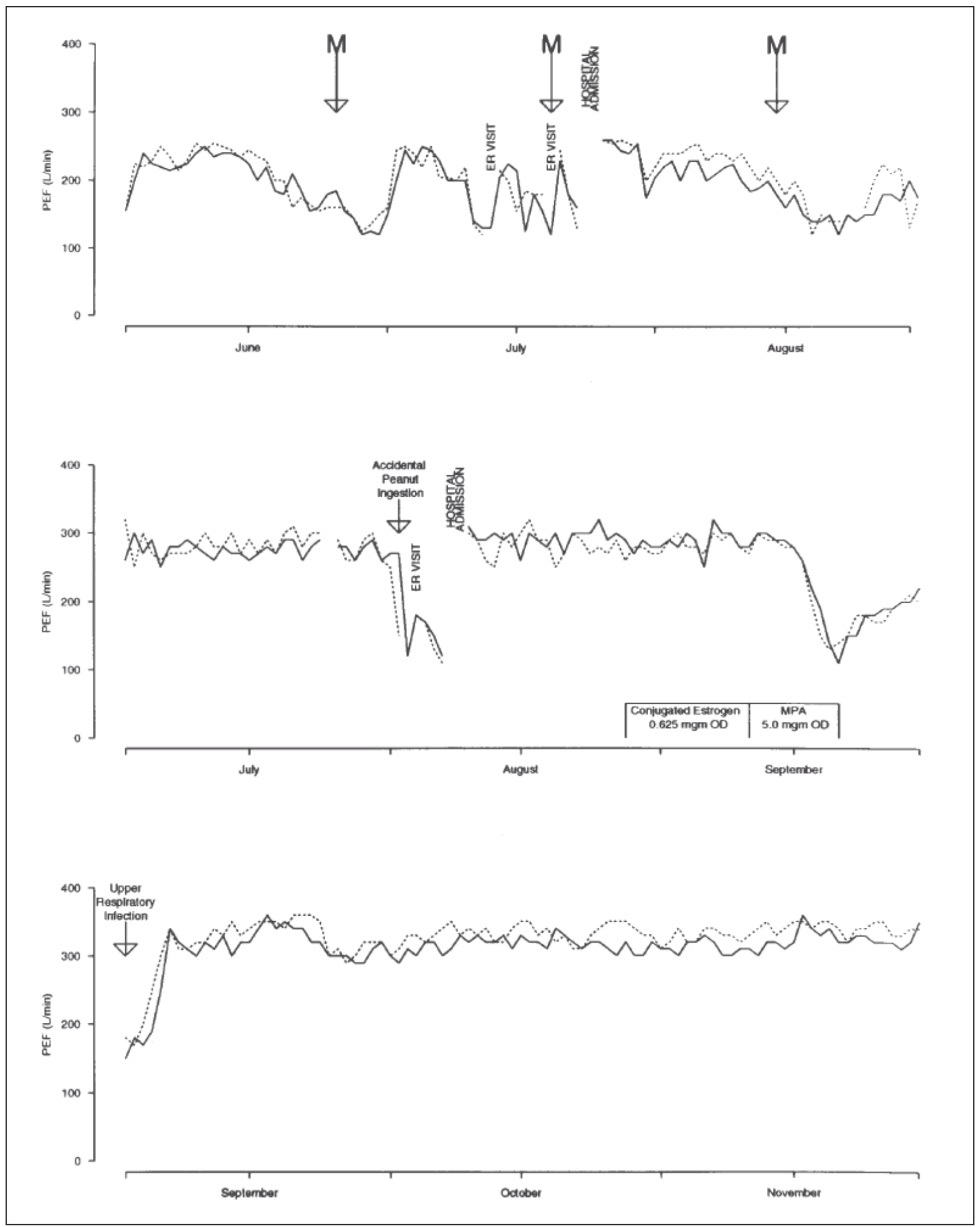

Figure 2) Morning (solid line) and evening (dashed line) peak expiratory flow (PEF) in L/min for three consecutive months in three consecutive years. Top Pre-gonadotropin releasing hormone (GnRH) analogue therapy; Middle GnRH analogue therapy with introduction of conjugated estrogen $0.625 \mathrm{mg}$ once daily followed by introduction of medroxyprogesterone acetate (MPA) $5.0 \mathrm{mg}$ once daily (as illustrated); Bottom Following bilateral salpingo-oophorectomy. ER visit Emergency room visit, M Commencement of menses, OD Daily 
dotal case reports have identified women with development of severe exacerbations of asthma perimenstrually, although attempts to study the problem systematically in groups of young asthmatic women have failed to show that the phenomenon is generalized, and the issue remains controversial $(1,3-5,7)$. It is recognized that asthma in children is slightly more common in boys than in girls, but the relative prevalence equalizes by the age of 14 when many girls will have achieved menarche $(9,10)$. Pregnancy also appears to have variable effects on the severity of asthma, though in many circumstances the condition is worse (11).

The mechanisms whereby gonadal steroids (or other hormones fluctuating predictably through the menstrual cycle) can alter bronchial reactivity remain the subject of hypothesis. Considerable attention has been devoted to progesterone, levels of which decline rapidly in the days before menstruation. This hormone also possesses mild immunosuppressive effects and has smooth muscle relaxant properties. Clinical studies of bronchial reactivity have failed to establish a progestogenic effect (7). The effects of progesterone therapy on asthma has been equally variable. Beynon et al (8) improved the control of asthma in a small group of women, whereas our patient clearly deteriorated, when medroxyprogesterone acetate was administered. A deterioration with progesterone therapy in patients with recurrent idiopathic anaphylaxis suggests that the potential immunomodulatory effects of the hormone may not be beneficial (12). The formulation and prescription regimen of progestins may be critical in determining the bronchial response.

GnRH analogues, such as buserelin, are finding an increasing role in the diagnosis and management of medical disorders that are affected by reproductive hormones (1216). These agents are agonists of the GnRH receptor, which by virtue of their prolonged action and occupancy of the receptors on the gonadotrophs in the pituitary lead to downregulation of the receptors and consequently reduced levels of luteinizing hormone and follicle-stimulating hormone. A menopausal state is thus induced and the production of gonadal steroids from the ovary considerably reduced. We decided to use buserelin in our patient as a means of establishing the premenstrual relationship with lifethreatening exacerbations, although the patient was fully aware of the rationale for the intervention and obviously could not be 'blinded' or given placebo because amenorrhea is a marker of therapy. We were impressed by the clinical improvement in the patient and our findings have been confirmed by others using GnRH analogues to treat asthma and recurrent idiopathic anaphylaxis (15). These agents offer the opportunity to treat asthma but also provide a 'clear field' so that replacement of gonadal steroids either singly or in a variety of regimens can be assessed for their effects on bronchospasm. This option of a reversible menopause can be used to assist in the therapeutic decisions affecting individuals or be a means of researching pathogenic mechanisms in menstrually related asthma.

Exacerbation of asthma with the menstrual cycle requires consideration in all young women, but particularly those with recurrent severe episodes. GnRH analogue therapy may provide a means of establishing this relationship in individual patients or in life-threatening circumstances may be a means of achieving improvement.

\section{REFERENCES}

1. Hanley SP. Asthma variation with menstruation. Br J Dis Chest 1981;75:306-8

2. Enright T, Lim DT, Devnani R, Mariano R. Cyclical exacerbation of clinical asthma. Ann Allergy 1987;58:452-3.

3. Elaisson O, Scherzer HH, DeGraff AC. Morbidity in asthma in relation to the menstrual cycle. J Allergy Clin Immunol 1986;77:87-94.

4. Juniper EF, Kline PA, Roberts RS, Hargreave FE, Daniel EE. Airway responsiveness to methacholine during the natural menstrual cycle and the effects of oral contraceptives. Am Rev Respir Dis 1987;135:1039-42.

5. Pauli BD, Reid RL, Munt PW, Wigle RD, Forkert L. Influence of the menstrual cycle on airway function in asthmatic and normal subjects. Am Rev Respir Dis 1989;140:358-62.

6. Gibbs CJ, Coutts II, Lock R, Finnegan OC, White RJ. Premenstrual exacerbation of asthma. Thorax 1984;39:833-6.

7. Weinmann GG, Zacur H, Fish JE. Absence of changes in airway responsiveness during the menstrual cycle. J Allergy Clin Immunol 1987;79:634-8.

8. Beynon HC, Garbett ND, Barnes PJ. Severe premenstrual exacerbation of asthma: effect of intramuscular progesterone. Lancet 1988;ii:370-2.

9. Martin AJ, McLennan LA, Landau LI, Phelan PD. The natural history of childhood asthma to adult life. BMJ 1980;280:1397-400.

10. Dawson B, Horrobin G, Illesley R, Mitchell R. A survey of childhood asthma in Aberdeen. Lancet 1969;i:827-30.

11. Gluck JC, Gluck PA. The effects of pregnancy on asthma: a prospective study. Ann Allergy 1976;37:164-8.

12. Meggs WJ, Pescovitz OH, Metcalfe D, Loriaux DL, Cutler G, Kaliner M. Progesterone sensitivity as a cause of recurrent anaphylaxis. N Engl J Med 1984;311:1236-8.

13. Cutler GB, Hoffman AR, Swerdloff RS, Santen RJ, Meldrum DR, Comite F. Therapeutic applications of luteinizing-hormone-releasing hormone and its analogues. Ann Intern Med 1985;102:643-57.

14. Casper RF. Clinical uses of gonadotrophin-releasing hormone analogues. Can Med Assoc J 1991;144:153-8.

15. Slater JE, Raphael G, Cutler GB, Loriaux DL, Meggs WJ, Kaliner M. Recurrent anaphylaxis in menstruating women: treatment with a luteinizing-releasing hormone agonist - a preliminary report. Obstet Gynecol 1987;70:542-6.

16. Blumenfeld Z, Bentur L, Yoffe N, Alroy G, Rubin AE. Menstrual asthma: use of a gonadotrophin-releasing hormone analogue for the treatment of cyclic aggravation of bronchial asthma. Fertil Steril 1994;62:197-200. 


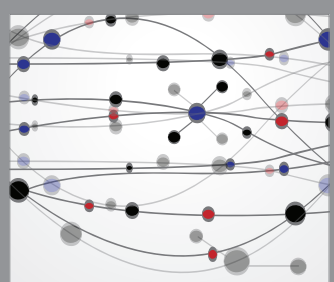

The Scientific World Journal
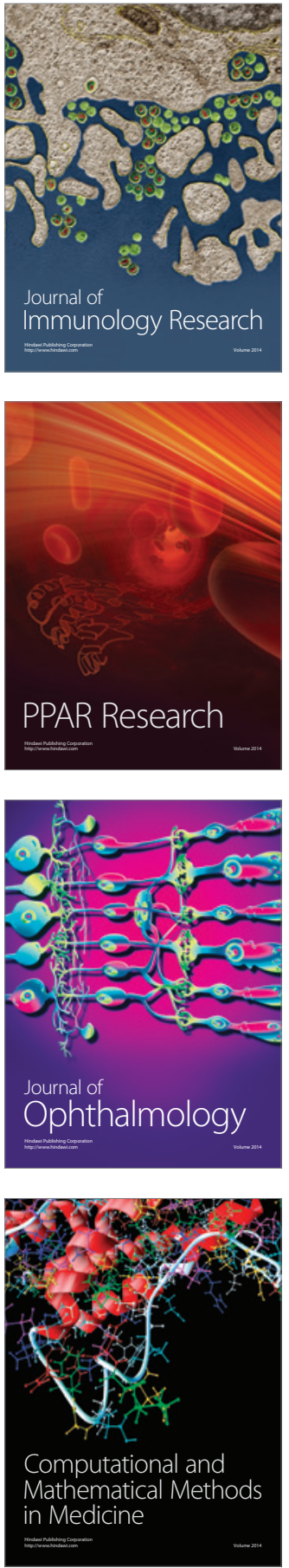

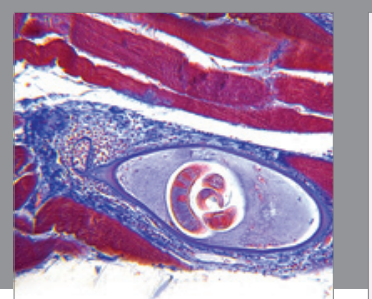

Gastroenterology Research and Practice

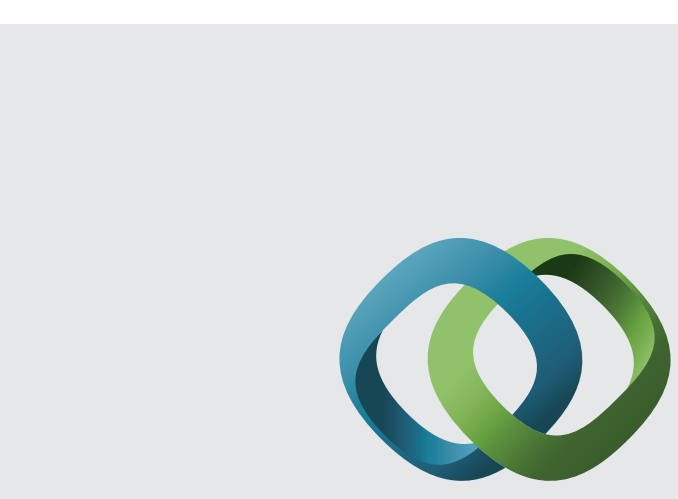

\section{Hindawi}

Submit your manuscripts at

http://www.hindawi.com
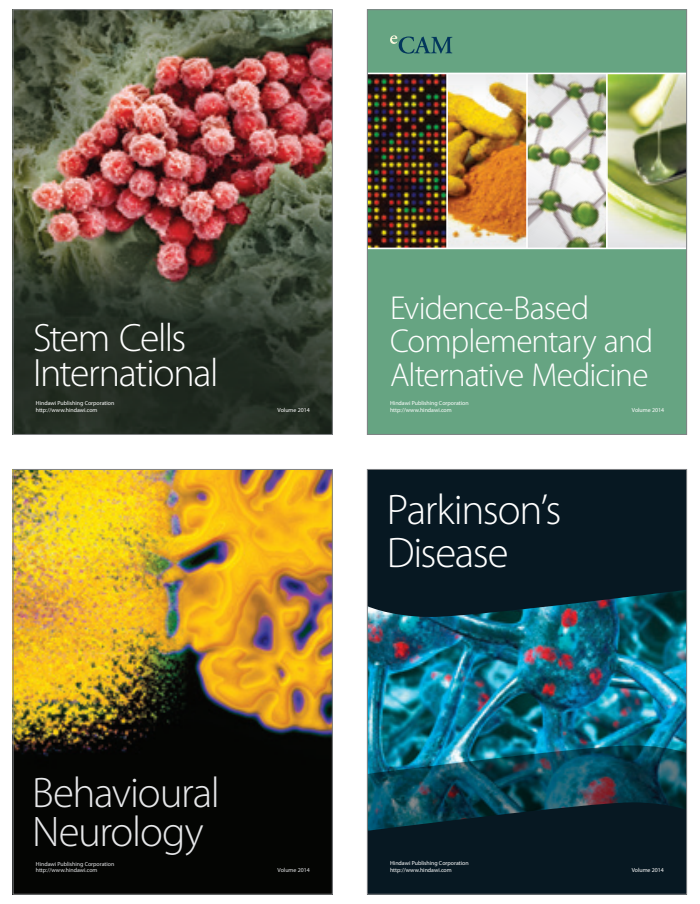
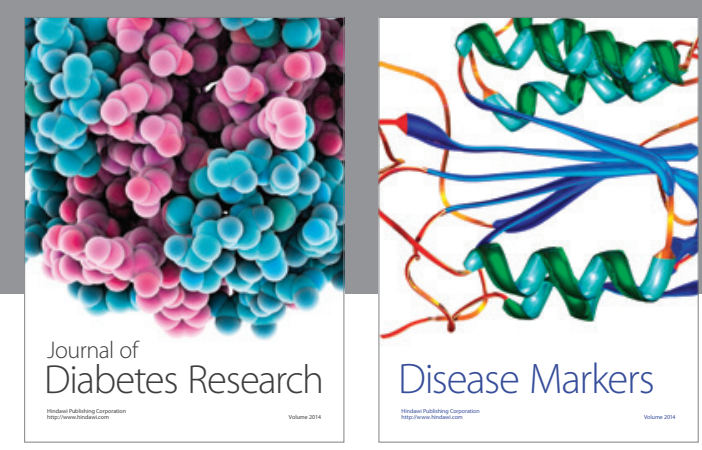

Disease Markers
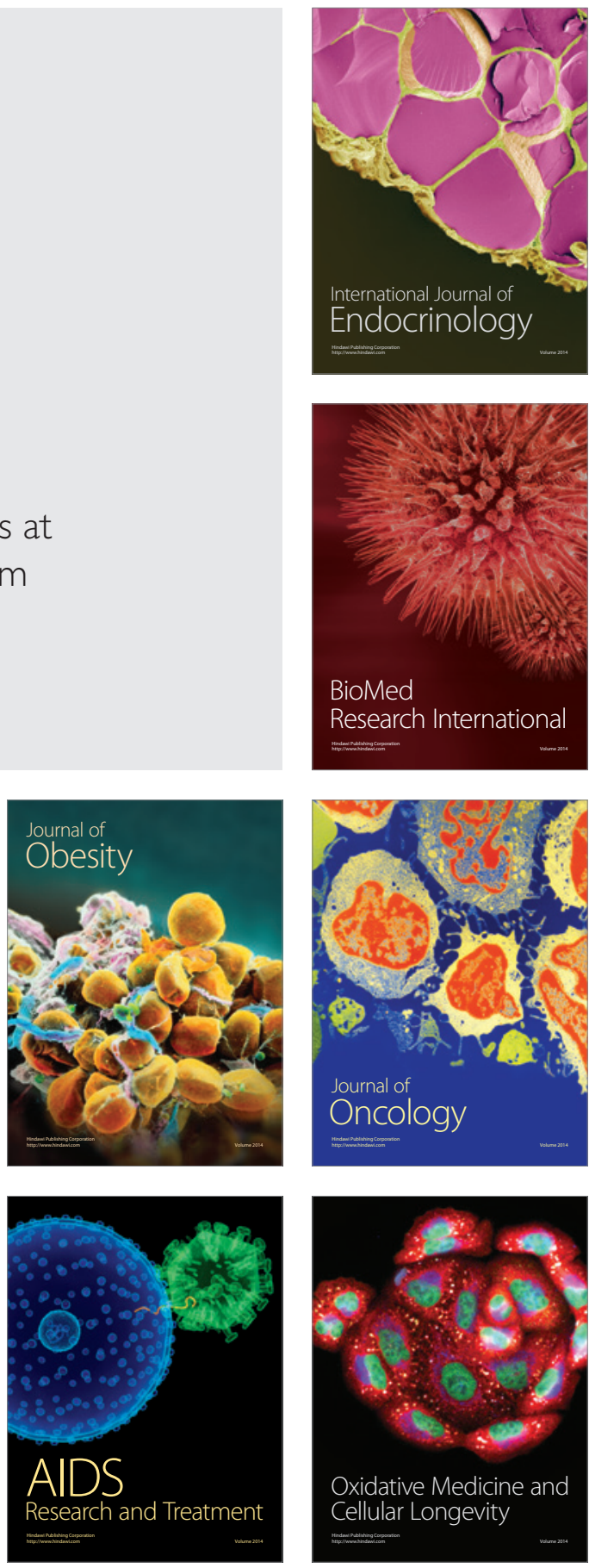